\title{
Africa's Child Soldiers/Suicide Children: A Regulatory Framework
}

\author{
Michèle Olivier \\ Department of Politics, Faculty of Business, Law and Politics, University of Hull, Hull, UK \\ Email address: \\ michele.olivier@hull.ac.uk

\section{To cite this article:} \\ Michèle Olivier. Africa's Child Soldiers/Suicide Children: A Regulatory Framework. International Journal of Law and Society. \\ Vol. 1, No. 3, 2018, pp. 115-124. doi: 10.11648/j.ijls.20180103.13
}

Received: October 8, 2018; Accepted: October 25, 2018; Published: November 21, 2018

\begin{abstract}
Despite the prohibition of child soldiers by international law, recent African conflicts have witnessed a persistence of this phenomenon, which is becoming ever more specialised. An example of such specialist involvement of children in African armed conflicts is the use of young children, especially girls as suicide bombers by the jihadist terrorist groups Boko Haram and Al-Shabaab. Using children in armed conflict is regarded as amongst the worst forms of child abuse under international law and African regional law. This article examines the almost unprecedented threat to the human rights of children created by child soldiers and specifically child suicide bombers with the objective of identifying major weaknesses in the responses by both general international law and African Union legal instruments. Despite the comprehensive engagement of international regulations with children in armed conflict, they are silent on the practice of using children for the specific purpose of suicide bombings. This article considers the question whether child suicide bombers can be considered to be child soldiers and as such should benefit from the regulations applicable to the latter category. This is established through an analysis of both the general international law and African Union legal frameworks on the rights of the child; child labour; children in armed conflict; and terrorism within the context of available information on the current wave of suicide bombings by young girls in West-Africa. It is suggested that child suicide bombings in a West-African context in effect constitutes a new form of improvised explosive device, but moreover should be regarded as a recognised form of child soldiering and terrorism. Although international law and scholarship do not provide adequate responses to this complex problem, it is suggested that child suicide bombings violate the letter and the spirit of the international regulations identified. This points to a clear need for more focussed scholarly research and comprehensive international engagement in order to understand and more effectively regulate this extreme form of child abuse within the already established context of children in armed conflict.
\end{abstract}

Keywords: African Union (AU), Child Soldiers, Human Rights, International Law, Suicide Bombers

\section{Introduction}

Today suicide attacks are by far the most dangerous form of improvised explosive device (IED) used in conflicts over the word. [1] It is suggested by Action on Armed Violence, a London-based organisation monitoring global explosive weapons that 'over 22 civilian casualties were recorded on average with each suicide attack that year (2014) - a figure that compares to fourteen in timer-operated IED attacks, six where command-operated IEDs were used and four in victim-activated IEDs.' [2] The increased use of children in suicide attacks has been steadily rising and is as common in African conflicts associated with Islamist terrorist activities, notably Boko Haram and Al-Shabaab, as it is elsewhere. [3]
The use of children in various roles during conflict provokes moral outrage, violates various national and international law provisions on child warfare and children's rights. Yet it is seemingly beyond control. Scholarship on suicide bombings mostly refer to Middle Eastern, Pakistani and Afghan case studies and focus on adults rather than on children. [4] Given the recent proliferation of child suicide bombings in West Africa (Nigeria, Chad and Cameroon) and East Africa (Somalia), the question arises as how these are dealt with under international law and African Union (AU) regulation. The body of international human rights law that has developed since WWII protects the rights of the most vulnerable including children, women, girls, and those sexually exploited, impoverished and tortured. Likewise, 
international law protects the security of the broader community by dealing with issues such as terrorism and crimes against humanity. From a human rights perspective, the use of children in conflict can be regarded amongst the worst forms of child abuse, yet the specific practice of child suicide bombings is not referred to by name. [5] A variety of different instruments, however, engages with a range of related issues such as recruitment of children, terrorism, children in armed conflict and the rights of the child more generally. As far as the African child suicide bomber is concerned, law and scholarship are lagging behind practice.

The apparent gap in regulation and scholarship leaves fundamental questions to consider. This article begins by positioning children and specifically young girls, as suicide bombers within relevant legal frameworks of international law and Africa-specific treaties which apply to the states in question. International instruments pertaining to women are also referred to as far as they would be applicable to the position of girls. Specific emphasis is placed on child rights, women's and girls' rights, recruitment of child soldiers, and the regulation of terrorism in order to gain a greater understanding of the recent phenomenon of suicide bombings within the broader context of the AU and general international law. By engaging with these issues, this article seeks to contribute to an understudied subject and encourage further research.

Research is primarily conducted through an analysis of primary sources such as international agreements of the UN and AU. Information gleaned from secondary sources such as media reports collected through open-source news websites and studies by NGOs and think tanks working on African conflicts and the use of IEDs, are used for contextualisation purposes in order to understand the implications within its particular setting. It is acknowledged that due to the obscure nature of suicide bombings, the political nature of these acts and the remoteness of the areas where it takes place, it is difficult to vouch for the accuracy of newspaper and NGO reports and statistics. However, the secondary material reporting these events is regarded as sufficient to indicate an alarming trend which justifies the research.

\section{Defining 'Child Soldiers'}

The uses of children in warfare seem to constantly diversify and become more specialised. [6] There appears to be no generally agreed definition of 'child soldiers'. Literature using it in the broad sense refers to child involvement in armed conflict. UNICEF adopts a broad definition of a 'child soldier' defining the concept as any child - boy or girl - under 18 years of age, who is part of any kind of regular or irregular armed force or armed group in any capacity, including, but not limited to cooks, porters, messengers, and anyone accompanying such groups other than family members. It includes girls and boys recruited for forced sexual purposes and/or forced marriage. The definition, therefore, does not only refer to a child who is carrying, or has carried weapons. [7] International humanitarian law distinguishes between combatant members of an armed force of a party to either an international or noninternational armed conflict who have the right to directly participate in hostilities versus civilians and non-combatant members of the armed forces who do not directly partake in hostilities and may not wilfully be attacked. [8] Whichever definition adopted, children recruited for suicide bombing are combatants who will fall within the scope of child soldiering and should be protected as such. Children of both sexes are now taking an active role in conflicts around the globe and girls are increasingly acting as suicide bombers. Whether abducted or recruited and indoctrinated by jihadi extremists, children turned suicide bombers are transformed into IEDs, dying on the crime scene with the victims.

Although current African conflicts where children are used as suicide bombers occur in particular states (Nigeria, Cameroon, Chad and Somalia), they spill over national borders, endanger human security and human rights at a continental level and present an unprecedented challenge to the AU.

\section{International Regulation of Child Soldiers Vulnerable to Be Deployed as Suicide Bombers}

Violent conflicts in Africa have led to thousands, mainly civilian, casualties since the turn of the century. [9] These conflicts involve the use of child soldiers, systematic rape, sexual abuse, kidnapping, torture and importantly various IEDs, such as child suicide bombers, as methods of warfare. Despite international prohibition of the use of child soldiers, an estimated 120,000 children in Africa have been reported to be directly involved in these armed conflicts either as part of national armed forces or various militia groups. [10]

\subsection{The Human Rights of Child Soldiers}

According to the 1989 Convention on the Rights of the Child (CRC), a child is considered to be a person below the age of 18. [11] The age limit is highly relevant because it unlocks the spectrum of human rights and protection to which children are entitled to under the CRC and which state parties are committed to protect. Many of these rights are without a doubt violated where children participate in armed conflict. They include the rights to life and not to be separated from their parents; freedom of expression, thought, conscience and religion; protection from discrimination; prohibition of any form of torture, punishment, abuse, neglect, sexual and economic exploitation; and the prevention of child abduction, trafficking and harm to children. [12] The CRC holds that in all decisions concerning children, the best interest of the child shall be a primary consideration and provides for special protection for children in need. [13]

The CRC devotes special attention to the issue of 'children in armed conflict'. Although refraining from using the term 'child soldiers', the latter broad and unspecific category is 
clearly what the CRC is directed at when referring to child participation in hostilities and recruitment into armed forces. [14] Article 38 of the CRC prohibits recruitment into the armed forces of children and participation in armed conflicts of those under the age of 15 . This provision can be regarded as controversial for allowing children under 18 but above 15 to be recruited and take direct part in hostilities. Recruitment is understood to refer to both compulsory and voluntary recruitment. [15]

In order to address unique challenges faced by the African child, the African Charter on the Rights and Welfare of the Child (ACRWC) was adopted by the Organisation of African Unity (OAU) and came into force in 1999. From a human security perspective the African child is vulnerable to famine, poverty, disease, low levels of literacy, gender discrimination, harmful cultural practices, child labour, sexual exploitation, lack of social security and displacement. The ACRWC covers the full spectrum of civil, political, economic, social and cultural rights and addresses a variety of issues pertinent to the African child that are not reflected in the CRC: The role of the family, parental care and responsibilities, responsibilities and duties of the child, socio- economic conditions, protection against harmful cultural practices and the age of child soldiers. [16]

Importantly, article 22 of the ACRWC deals with children in armed conflict. This provision increases the level of protection for children compared to the CRC by providing that no child (person under 18) shall either be recruited or participate in hostilities. African states who are a party to both the CRC and the ACRWC are obliged to follow the higher level of protection provided by the latter. [17] All African states are party to the CRC. [18] Nigeria, Cameroon and Chad have ratified the ACRWC, whilst Somalia has only signed it to date. [19] As parties, states are required 'to adopt such legislative or other measures as may be necessary to give effect to the provisions of this Charter.' [20]

It is evident that involving children as active role players in armed conflict cannot be regarded to be in their best interest and violates the letter and spirit of the $\mathrm{CRC}$ and ACRWC.

\subsection{Recruitment of Child Soldiers/Suicide Bombers}

The issue of child recruitment into military activity has always been an international hot potato. The low age limit of 15 set for recruitment by the $\mathrm{CRC}$ remained a cause for concern within the international community. [21 Many of the state parties expressed their dissatisfaction through reservations to article 38 of the CRC. [22] Article 38 in fact conflicts with International Labour Convention 182 on the Prohibition and Immediate Action for the Elimination of the Worst Forms of Child Labour, which prohibits forced and compulsory recruitment of under 18 year olds for participation in armed conflict. [23] Hence an Optional Protocol to the CRC on Children in Armed Conflict (Optional Protocol) was adopted in 2000 in an effort to settle the age issue and to reflect the changing face of international conflict. [24] Under the Optional Protocol states agree to ensure that members of their armed forces who are under 18 years do not take a direct part in hostilities; raise the age for compulsory recruitment to the age of 18 ; and raise the age for voluntary recruitment from 15. [25] Moreover, nongovernment armed forces should not, under any circumstances, recruit or use in hostilities persons under the age of 18. [26] Recruitment must be carried out with the informed consent of parents or legal guardians. [27] The Optional Protocol's contribution lies not only in raising the age for compulsory recruitment to 18 and limiting voluntary recruits from direct participation but in imposing the age limit of 18 on non-state groups. The onus rest on states to take all feasible measures to prevent these practices through criminalisation. [28] This provision will directly impact on the recruitment of children to be used as IEDs such as suicide bombers. African states Nigeria, Chad and Cameroon have all ratified the Optional Protocol making them legally bound to enforce its provisions. Somalia has only signed but not yet ratified it. [29]

The high benchmark of 18 set for recruitment by the ACRWC have all but erased child recruitment by nongovernmental forces in Africa taking on various forms, be it voluntary or forced. Child abduction as a method of recruitment is common in African conflicts. It was general practice within the RUF (Revolutionary United Front) in Sierra Leone, Darfur and the LRA (Lord's Resistance Army) in Uganda. [30]

When turning to potential child bombers by Islamist groups, recruitment have become all the more innovative and forceful - often a result of child abduction and trafficking. These transactions are conducted for profit and not necessarily to further extremist beliefs. [31] Concerns of child abduction, sexual exploitation and slavery are addressed in a second Optional Protocol to the CRC on the Sale of Children, Child Prostitution and Child Pornography obliging state parties to criminalise these acts under domestic law. [32] The sale of children would cover instances where children are transferred to another to be turned into child soldiers/suicide bombers for remuneration or any other consideration.

To deal with the specific challenges faced by African women and girls, the 2005 Protocol to the African Charter on Human and Peoples' Rights on the Rights of Women in Africa calls on states to eradicate and criminalise violence against women; and to prevent trafficking of women. [33] Article 11 deals with protection of women in armed conflicts; providing for protection against all forms of violence, rape and other forms of sexual exploitation. Such acts are considered war crimes, genocide and/or crimes against humanity and their perpetrators are to be prosecuted. Article 11(4) specifically provides that: 'States Parties shall take all necessary measures to ensure that no child, especially girls under 18 years of age, take a direct part in hostilities and that no child is recruited as a soldier.'

However, not all children are forcibly recruited despite being under the age of lawful consent. Joining the military or a militia group seems like a way out for many children, 
particularly girls wanting to escape poverty, the confines of a traditional lifestyle, Islamic gender roles and a patriarchal society. It might also be seen as a way to get an education, obtain skills and gain independence. [34] African conflicts often take place against the background of traditional and religious values and belief systems that are observed alongside the official legal system of the state. [35] These systems often endorse a patriarchal structure of societies as outlined by Wison, where women's rights enjoy limited protection and self-sacrifice by women can be regarded as a culturally condoned phenomenon. [36]

\subsection{Child Soldiers Turned Suicide Bombers}

Child suicide bombers take child soldiering to the next level but remain absent from international regulation. It is a phenomenon often associated with the Islamist conflicts, specifically the Palestinian/Israeli, Pakistan and Afghanistan instead of African conflicts. The Chicago Project on Security and Threats (CPOST) maintains the CPOST Suicide Attack Database currently available, and contains the most complete list of suicide attacks since 1982. [37] CPOST defines a 'suicide attack' as 'an attack in which an attacker kills himself or herself in a deliberate attempt to kill others.' CPOST includes only suicide attacks perpetrated by nonstate actors. The classic example is a suicide bomber detonating an explosive vest (a 'belt bomb') or explosives in a vehicle the bomber is driving (a 'suicide car bomb'). [37]

According to the CPOST website, suicide bombings occurred in the following African states: Algeria, Cameroon, Chad, Egypt, Kenya, Niger, Nigeria, Mali, Morocco, Mauritania, Tanzania, Somalia, and Djibouti during the period 1982- 2016. According to data released by CPOST, female suicide bombings in this period were limited to Cameroon, Chad, Nigeria, Somalia, and Djibouti with the majority occurring in Nigeria (47) and Cameroon (10). Female suicide bombings first occurred in Somalia in 2006 followed by the next attempt in Nigeria in 2014 after which the frequency escalated. [37] No record is given of the age of the female suicide bombers, although the use of children is acknowledged. According to UNICEF data released on 12 April 2016, 'the number of children involved in 'suicide' attacks in Nigeria, Cameroon, Chad and Niger has recently risen sharply, from 4 in 2014 to 44 in 2015 . More than 75 per cent of the children involved in the attacks are girls. In 2015, children were used in 1 out of 2 attacks in Cameroon, 1 out of 8 in Chad, and 1 out of 7 in Nigeria.' [40] UNICEF makes an urgent call that more needs to be done to assist these children exposed to extreme violence.

\section{Girls and Woman as Preferred Suicide Bombers}

In line with tradition and African patriarchal societies, girls usually played a variety of subordinate roles in war limited to supporting those in active combat through various means. [39] In the Mozambique conflict (1977-1992) both
FRELIMO an RENAMO used girl recruits as fighters but also as spies, intelligence officers, trainers, medics and labourers collecting water and wood and so forth. In Angola (1975-2002) they were used to entertain troops and keep the morale high. [39] This has changed as girls are increasingly involved in political violence and their human rights are abused at all levels. Compared to boys, the position of girls is, however, made more complex when considering the added influence of gender based violence. The importance of a gendered perspective to the prevention and resolution of conflicts as well as the maintenance and promotion of peace and security is acknowledged by Security Council resolution 1325 on women and peace and security of 2000. [40] Resolution 1325 calls on all parties to conflicts to take special measures to protect women and girls from genderbased violence, particularly rape and other forms of sexual abuse, in situations of armed conflict. The position of girls is interesting from a regulatory perspective as they simultaneously straddle regimes directed at women and children. Many scholars have explored a wide variety of aspects of women/girls as suicide bombers in different regions and from different perspectives including security studies, counter-terrorism, feminism and gender-based violence. [41] These include Von Knop on what motivates the female jihad, to Butler and Jacques who consider the terrorist nature of female suicide attacks. [42] Bloom suggests that female suicide bombers have become a globally growing trend. Although not limited to Islamist conflicts, suicide bombings have strong religious militant connotations. [3] This trend has spilt over to the African Islamist conflicts (Boko Haram and Al Shabaab). In the words of Laurent Duvillier, regional spokesperson for the United Nations Children's Fund (UNICEF) "The use of children, especially girls, has become a defining and alarming feature of this (Boko Haram) conflict.'[43] A regional regulatory context has yet to be actively explored by scholars, underlying the need for focussed research.

The use of women, especially girls, as suicide bombers is an innovative method of warfare fuelled by strategic considerations. The wide range of reasons for using women in warfare differ depending on the particular conflict. [44] There are different views on whether it also reflects societal changes on gender roles. Either women are regarded as equals and as capable as men to carry out important roles or, in the case of a preference to use women/girls as suicide bombers, it might indicate the exact opposite, namely that women are dispensable - cannon fodder to be sacrificed for a strategic goal. [45] It might also be a tactical response to provide more 'manpower'. Be it as it may, girls are no longer regarded as the weaker sex limited to supporting male soldiers at the frontline. Girls and boys acting as suicide bombers are perpetrators of violence yet remain victims of child abuse and possibly war crimes.

\section{A West African Case Study}

Boko Haram child suicide bombings have surged in West 
Africa with children as young as 8, mostly girls, detonating bombs in schools and markets. The escalating conflict in Nigeria which has spread beyond its borders, underlining the regional and international flavour of the conflict, serves as a case study. Jama'atu Ahlis Sunna Lidda'awati wal Jihad, also known as Boko Haram (which means 'Western education is a sin' in the local Hausa language), was created in 2002 in Maiduguri, capital of Nigeria's north eastern Borno state. Its objective is to overthrow the government and establish an Islamic state governed by Sharia law. Boko Haram increased its operational capability from rudimentary Molotov cocktails against Christian targets in 2010 to vehicle-borne IEDs against the police headquarters in Abidja in 2011, to transnational targets using commercial explosives in 2014. Both the state and civilians are targeted. Sexual exploitation and rape are used as instruments of war. According to the Children in Armed Conflict Report to the UN Security Council of 15 May 2014, the Nigerian Jihadist terrorist organisation carried out 64 suicide attacks since 2011 of which 32 were conducted in 2014. [46] Boys are sensitised to Islamic values by almajiri schools and open to potential radicalisation. [47] Hoechner, however warns that there is no systematic evidence to support assertions of radicalisation. [48] The incidence, however, steadily increased, spiking at certain periods. It is suggested that Boko Haram is copying jihadi tactics followed in Iraq and Afghanistan. [47] Concerns were fuelled when four teenage girls carried out attacks in Kano, a northern Nigerian city within one week (July 2014). At the same time it was reported that two girls, one as young as 10 , were arrested in neighbouring Katsina state with explosive belts strapped around them. [48] Five children, four girls and one boy, were reported to be responsible for a series of blasts in the north-eastern Nigerian city of Maiduguri in October 2015, killing 15 and injuring 35 . The children involved were reported by eye witnesses to be between 9 and 15. [49]

Attacks appeared to spike again by the end of December 2015 following President Muhammadu Buhari's 31 December deadline to end terrorist activities in the country. On 27 December, 14 female suicide bombers between the ages of 12 and 18 attempted to attack Maiduguri. All but three of the attackers were intercepted by troops on patrol, killing twenty-six people and injuring 85. [50] The next day two suspected female suicide bombers detonated themselves at Madagali Market in Adamawa State, killing 17 people and injuring 44 others. [51]

Also associated with the Boko Haram conflict, suicide attacks carried out by two young girls on the Cameroonian town of Maroua on 22 July 2015 killed at least 20. One of the girls was a nine year old posing as a beggar. [52] This resonates with reports from central Asian states that 'Children are usually outfitted with IEDs, which are remotely detonated. Sometimes the children don't even know what they are actually doing.' [53] On 29 December 2015, following the Nigerian governments announcement of victory over Boko Haram, an attack was carried out by two Nigerian girl suicide bombers believed to belong to Boko
Haram at a market in Cameroon's far north region, killing only themselves. [54]

The examples cited above point to a trend that children used in these attacks are getting younger which inevitably attract greater media attention. Where 15,16 and 17 year olds guaranteed headlines in the past, media attention now focus on pre-teens, such as the 10 year old in the July 2015 attack in northern Nigeria. [55] The use of girls initially led to speculation that they belonged to the group of more than 200 girls abducted in April 2013 from their school in the town of Chibok in Borno State, Nigeria. Other theories advanced are that suicide bombers include homeless children, the poor and desperate doing it in return for financial rewards. [56] It is even suggested by a Nigerian based security analyst that female suicide bombers are likely to be children of Boko Haram members who believe that they are waging a holy war. [48]

Women and children may be completely unaware that they are about to blow themselves up or be blown up by remote control. The Nigerian Minister of Information and Culture, reacting to the spate of bombings perpetrated by teenage girls revealed that most female suicide bombers being used by the Boko Haram are unaware that they are carrying bombs:

"Suicide bombers usually walk in threes. There is the man who leads. The leader will ensure that the small girl who is strapped with the bomb knows the road. The small girl never knows what she is carrying. She is simply told to go and deliver a parcel at a market. That leader would have taken her to the market days before to show her the direction of the market. On the day she is to deliver the package, the man will lead and by then she is strapped. Then there is another person that tails her from behind who will make sure that she doesn't change her mind or turns in another direction. These bombs are detonated remotely. This is how cowardly these people are. These girls are not indoctrinated. Most of them don't know what they are carrying. Some of them do it for as little as N5,000 which is given to their parents."[57]

Predictably the targeting of children has raised concerns with rights activists and the NGO community. One such NGO, Girl-Child Rights Awareness Initiative in Africa, has called for urgent action against female suicide bombers in northern Nigeria. The group's Executive Director, reacting to latest suicide bombings in Madagali, Adamawa and Maiduguri, made a call for urgent action to save the girlchild. According to her, suicide bombings add to the many other challenges facing the girl-child in the northern part of the country, such as child marriage and illiteracy. There is an urgent need to orientate girls to be aware of 'the tricks of unscrupulous elements who take advantage of their naivety and innocence'. [58]

These instances of children used as suicide bombers cited above are clear violations of the CRC, Optional Protocol, the ACRWC and possible other treaties dealing with child labour and trafficking by non-state actors making state parties responsible to take all feasible measures to prevent such practices through criminalization. Using children of both sexes ticks the same boxes as using women by erasing 
barriers between combatants and non-combatants and gaining access to no-go areas for men. The gender perspective that girls and women bring, however, adds another layer of complexity. All the arguments explaining why women are used in war similarly apply to children, yet their special vulnerability place children, especially girls, in an even more precarious position when compared to women. They are more vulnerable, easier to manipulate, lack the legal capacity to contract, are uneducated, without their own resources and thus easier to influence. [59]

\section{Suicide Bombing as Terrorism}

Child suicide bombing as a form of child soldiering simultaneously manifests as acts of terrorism under international law as well as the AU. The AU regulation of terrorism is of particular significance as it applies to the Islamist conflicts in West and East Africa. The OAU's 1994 Declaration on the Code of Conduct for Inter-African Relations pledged to fight extremism and terrorism 'whether under the pretext of sectarianism, tribalism, ethnicity or religion'. [60] The need for cooperation between OAU member states in dealing with terrorism was underlined with the adoption of the Convention on the Prevention and Combating of Terrorism in 1999 (Terrorism Convention). [61] The Terrorism Convention is relevant in various respects to the debate on child soldiers/suicide bombers: It recognises that women and children are most adversely affected by terrorism whilst acknowledging that terrorism constitutes a serious violation of human rights. It acknowledges 'the growing link between terrorism and organized crime, including the illicit traffic of arms, drugs and money laundering'. [61] A further aspect of significance is the obligation placed on parties to criminalise terrorist acts. [62] Acts of terrorism are defined by article 3(1) as: (a) any act which is a violation of the criminal laws of a State Party and which may endanger the life, physical integrity or freedom of, or cause serious injury or death to, any person, any number or group of persons or causes or may cause damage to public or private property, natural resources, environmental or cultural heritage and is calculated or intended to: (i) intimidate, put in fear, force, coerce or induce any government, body, institution, the general public or any segment thereof, to do or abstain from doing any act, or to adopt or abandon a particular standpoint, or to act according to certain principles.

Using children as soldiers, more specifically as suicide bombers clearly falls under this definition. The topic of suicide terrorism is well researched by scholars. Pedahzur and others regard it as a potent tool both for making grandiose public statements and as a means of engaging militarily superior opponents or difficult targets and is highly successful to put pressure on governments and get terrorist demands met. [4] Children may be perpetrators or victims of acts of terrorism - or both if it is considered how their human rights are violated by recruitment and or abduction. Those responsible for the recruitment and use of children as soldiers/suicide bombers will likewise fall under the definition of an act of terrorism and thus be criminally liable. The African states where child suicide bombings occur are parties to the Terrorism Convention with the exception of Cameroon and Somalia who have at this date signed but not yet ratified it. In 2004 a Protocol to the Terrorism Convention was adopted reflecting the increased incidence and growing sophistication of terrorist acts globally and in Africa and the growing link between terrorism and various criminal activities. [63] Countering terrorism and violent extremism in Nigeria is closely linked to criminal activities. [41] The African states where suicide bombings occurred, have all signed but not yet ratified this protocol.

Where children are consciously used in terrorist activities, identification with an ideological cause is essential, and training and indoctrination are very important. Cooperation and commitment of the suicide bomber are needed to the extent that they are prepared to martyr themselves for a cause. Wessells remarks that '... by fighting oppression, girl soldiers may find meaning in terrorist activities, regarding them as the highest expression of their social identity and commitment to the group struggle.' [64]

This does not include the category of children forcefully recruited to act as suicide bombers against their will or unaware that they are acting as such. It is very difficult to gain accurate information as to whether children are groomed to commit these acts, whether they are forced or if they are aware of the fact that they are about to kill themselves and others. The use of young children raises doubts as to radicalisation but rather points in the way of the children being either unaware of what they are doing or having no option other than to cooperate. Because the child perpetrators in successful incidences of suicide bombings are no longer available to provide evidence, the only available data will come from children involved in unsuccessful attempts and secondary sources of information. In all cases it is suggested that the adult responsible of using a child as an IED should be held accountable for an act of terrorism.

\section{Where Does International Regulation Leave the Child Suicide Bomber}

The absence of direct and relevant regulation of the issues surrounding child suicide bombers is problematic in the light of its increased incidence, particularly as far as girls are concerned. Instead, international regulation deals with child protection issues and regulate recruitment and participation of children in armed conflict. From the analysis of treaty provisions, the following issues relate to child suicide bombers:

1. Their human rights as children are violated at multiple levels through exploitation and abuse and as such pose a clear and grave violation of the $\mathrm{CRC}$ and the ACRWC. Moreover, it would constitute a flagrant violation of the 'best interest of the child' principle;

2. Using children under 15 as suicide bombers would 
imply active participation on top of the requirements of conscription or enlisting, violating the Rome Statute of the International Criminal Court, thus qualifying as a war crime.

3. Use of voluntary under 18-year olds to participate in hostilities through suicide bombings would violate the recruitment provisions of the Optional Protocol.

4. Child suicide bombers can be both victims and perpetrators of acts of terrorism and war crimes.

5. Under the Protocol to the African Charter on Human and Peoples' Rights on the Rights of Women in Africa girls enjoy special protection in armed conflict. State parties are obliged to eradicate and criminalise violence and trafficking of girls and protect them from recruitment, participation in hostilities, rape and other forms of sexual exploitation. In addition to constituting crimes at a national level, such acts are also considered war crimes, genocide and/or crimes against humanity.

6. African instruments on human rights and recruitment provide more comprehensive protection compared to UN treaties. However, compliance with these standards by non-state parties to African conflicts appear to be hampered by values subscribed to by patriarchal traditional societies in the grip of poverty. Islamist conflicts capitalise on these features of vulnerable African societies.

Given the recent nature of the surge in child suicide bombings, it is perhaps not surprising that none of the above treaties of which the most recent was adopted as far back as 2000 , address the phenomenon by name. International law and scholarship do not provide adequate responses to this complex problem. [65] Where treaties fail to address a specific matter in sufficient detail, regard is had to the existence of rules of customary international law established by state practice regarded as binding by subjects of the international community. [66] Given the often lengthy period it takes for customary international law to crystallise, it is suggested that it would not add much to the existing body of rules applicable to child suicide bombers.

It is clear that suicide bombers fall within the scope of 'children in armed conflict' and may thus not be compulsory recruited or used in hostilities by armed groups as set by the Optional Protocol. [67] At a popular level the basic question to be answered is whether child suicide bombers can be considered to be child soldiers. Like child suicide bombings, the generally recognisable label of 'child soldiers' is also not derived from international treaty law, yet lends itself to a wide and a narrow interpretation. A wide definition of a 'child soldier' will refer to all children participating in hostilities at any level. [68] A narrow interpretation will refer only to those involved in actual combat. Child suicide bombers will be covered under both approaches. It is therefore suggested that using children as suicide bombers can be considered as child soldiering and constitutes a violation of international law.

However, whilst direct participation in hostilities or child soldiering cover a wide range of activities, child suicide bombing is a very specific example of how child soldiers can be used in conflict. International law, more than African responses display major weaknesses. There are no specific and comprehensive measures in place and the fragmented regulations that do exist are not enforced within Boko Haram, an Islamic non-state terrorist group. It is suggested that this distinct category of children in armed conflict/ child soldiers should receive special focus enabling timeous detection. There is a need for focused scholarly research and consideration by international decision-making bodies in order to understand and control this wave of extreme child abuse.

\section{Conclusion}

There is a clear relationship between child insecurity and the use of child soldiers and child, especially girl, suicide bombers in West and East African Islamist conflicts. The Boko Haram and Al Shabaab conflicts which started in Nigeria and Somalia, have now moved beyond national borders taking on an international colour. As such it is justified to describe the peculiar characteristics of these complex phenomena as a challenge to the African continent as a whole demanding the attention of the AU.

Research suggests that children are recruited under various pretexts such as education, escape from extreme poverty, traditional lifestyles and the devastating effects of war. In the case of the preteen and teenage girls used in the Boko Haram conflict evidence points to abduction, force and manipulation instead of voluntary recruitment. Despite Islamic values embedded in children, it is not so much a case of radicalisation of potential bombers but rather of abuse turning girls into living IEDs. Accountability for such crimes should be on the adults orchestrating the crimes as acts of terrorism. Should a child somehow survive a failed suicide bombing, they might be held accountable under international and domestic law but should rather be used as witnesses instead of accused.

It is suggested that exploiting children as suicide bombers constitutes one of the worst forms of child abuse and violates their human rights at multiple levels. Using children 'kamikaze style' directs the attention away from the fact that these children are actually child soldiers who are victims of crime and entitled to protection under African and international law. Children should be intercepted and protected before killing themselves and others through suicide bombings. It is suggested that in the light of the global shift to a comprehensive approach of human security, there should be greater awareness of how exploitation of children's internationally recognised human rights is linked to suicide bombings.

The review provided of child protection under international law points to the fact that child suicide bombing is not a recognised category of children in armed conflict. Neither existing international nor specifically African legal and regulatory frameworks provide adequate responses. Given definitional disagreements on the term 'child soldiers' and fragmented and inadequate regulation and enforcement 
of international law, potential child suicide bombers often slip through the net of legal protection. Their plight only reaches the headlines when it is too late.

\section{References}

[1] An IED is a type of unconventional explosive weapon that can take any form and be activated in a variety of ways according to NATO 'Improvised Explosive Devices' http://www.nato.int/cps/en/natohq/topics 72809.htm (Accessed 10/05/2018).

[2] Hunter, J. (10 August 2015) https://aoav.org.uk/2015/2015-anepidemic-of-suicide-bombs/ (Accessed 10/05/2018).

[3] Bloom, M. (2007) Female Suicide Bombers. Daedelius 2007, 136(1), p. 94-102.

[4] Recent studies that exist include those by Robert. A. Pape, Director of the Chicago Project on Security and Terrorism. See Pape, R. A. \& Feldman, J. K. (2010) Cutting the Fuse: The Explosion of Global Suicide Terrorism and How to Stop It, Chicago; Pape, R. A. (2005) Dying to Win: The Strategic Logic of Suicide Bombing, New York 2005; S. Atrane, The Moral Logic and Growth of Suicide Terrorism. The Washington Quarterly, 29 issue 2, 2006, p. 127-147; Atrane, S. (2003) Genesis of Suicide Terrorism. Science 299, issue 5612, March 2003, p. 1534-1539; Atrane, S. (2004) Mishandling Suicide Terrorism. The Washington Quarterly 27 issue 3, 2004, p. 65-90; Ashworth S. et al (2008) Design, Inference and the Strategic Logic of Suicide Terrorism. American Political Science Review, 102 issue 02 May 2008, p. 269-273; Pedahzur, A. (2005) Suicide terrorism, Cambridge 2005; and Crenshaw, M. (2007) Explaining Suicide Terrorism: A Review Essay. Security Studies, 2007, 16 issue 1, p. 133162.

[5] De Silva, H., Hobbs C.\& Hanks H., (2001) Conscription of Children in Armed Conflict - A Form of Child Abuse. A Study of 19 Former Child Soldiers. Child Abuse Review, 2001, p. 125-134.

[6] Report of the Secretary General 'Children and armed conflict' $\mathrm{A} / 59 / 695-\mathrm{S} / 2005 / 72$.

[7] Factsheet: Child
http://www.unicef.org/emerg/files/childsoldiers.pdf, (Accessed 10/05/2018).

[8] This distinction was implied by the Regulations of the Hague Convention IV of 1907, and is according to Boczek, an established principle of international humanitarian law. See Boczek, B. A. (2005) International Law A Dictionary, Oxford 2005 , p. 422.

[9] Elbadawi, I. \& Sambanis, N. Why are there so many civil wars in Africa? Understanding and preventing violent conflict, Journal of African Economics 9, issue 3, p. 244-245; Bugnacki, and J. Critical Issues Facing Africa: Terrorism, War, and Political Violence, 17 January, http://www.americansecurityproject.org/critical-issues-facingafrica-terrorism-war-and-political-violence/Bugnacki 2015, http://www.americansecurityproject.org/critical-issues-facingafrica-terrorism-war-and-political-violence/ (Accessed 17/01/ 2018).

[10] There is no reliable quantitate data on the number of child soldiers in Africa partially due to the absence of a concise and agreed definition. The figure of 120000 has been used continuously since the 1990s. See Waschefort, G. (2015) International Law and Child Soldiers, Oxford, p. 26.

[11] Adopted and opened for signature, ratification and accession by General Assembly. Resolution 44/25 of 20 November 1989.

[12] Convention on the Rights of the Child, Articles 6(1), 9(1), 12, $13,14,2,37,9(1), 19,34,32,11,35$ and 3.

[13] Convention on the Rights of the Child, Articles 3(1) and 20.

[14] Convention on the Rights of the Child, Article 38.

[15] Cohn, I. \& Goodwin-Gill, G. (1994) Child Soldiers: The Role of Children in Armed Conflict, p. 62.

[16] African Charter on the Rights and Welfare of the Child, Articles 18, 19, 20, 31, 14, 11(3), 21 and 22.

[17] Article 1(2) of the African Charter on the Rights and Welfare of the Child: "Nothing in this Charter shall affect any provisions that are more conductive to the realization of the rights and welfare of the child contained in the law of a State Party or in any other international Convention or agreement in force in that State.'

[18] https://treaties.un.org/Pages/Content.aspx?path=DB/titles/page 1_en.xml. (Accessed 20/01/2018).

[19] http://www.achpr.org/instruments/child/ratification/. Somalia have signed the ACRWC on 01/016/1991 but not yet ratified. (Accessed 20/07/2017).

[20] African Charter on the Rights and Welfare of the Child, Article 1(1).

[21] Happold, M. (2001) Child soldiers in international law: The regulation of children's participation in hostilities, Netherlands International Law Review, 47 Issue 1: 28, 2000, p. 28.

[22] Olivier, M. (1999) Children in armed conflict: Draft Optional Protocol to the Convention on the Rights of the Child, South African Yearbook of International Law, 24: 248 1999, p. 2489.

[23] Adoption Geneva, 87th ILC session, 17 June 1999.

[24] UNGA resolution 54/263.

[25] Optional Protocol to the CRC on Children in Armed Conflict Articles 1, 2 and 3(1).

[26] Optional Protocol to the CRC on Children in Armed Conflict, Article 4(1).

[27] Optional Protocol to the CRC on Children in Armed Conflict, Article 3(3)(b).

[28] Optional Protocol to the CRC on Children in Armed Conflict, Article 4(2).

[29] https://treaties.un.org/Pages/ViewDetails.aspx?src=IND\& mtdsg no $=I V-11-b \&$ chapter $=4 \&$ lang $=$ en. 20/01/2018).

[30] Drumbl, M. (2012) Reimagining Child Soldiers in International Law and Policy, Oxford, pp. 34-35, 177; Dallaire, R. (2011) They Fight like Soldiers, They Die Like Children, London 2011, pp. 123-123; Wessells M. (2009) Child Soldiers, Cambridge, Massachusetts, p. 39. 
[31] Hunter, I. Muslim boys are being kidnapped and brainwashed as suicide bombers before being traded by jihadis at $£ 30,000$ a time, MailOnline, 2016, http://www.dailymail.co.uk/news/article-3382674/Muslimboys-kidnapped-brainwashed-suicide-bombers-tradedjihadis-30-000-

time.html? ITO $=1490 \& n s$ mchannel $=r s s \& n s$ campaign $=14$ 90 (Accessed 4/01/2018); J. Hinton, Evil jihadis kidnap thousands of boys to sell as suicide bombers at $£ 30 \mathrm{k}$ a time. Thousands of Muslim boys are being kidnapped to be traded as suicide bombers." 3 January 2016, http://www.dailystar.co.uk/news/latest-

news/484934/jihadis-kidnap-child-terrorists-Pakistan, (Accessed 15/01/2017).

[32] Entry into force 18 January 2002, Article 3.

[33] Protocol to the African Charter on Human and Peoples' Rights on the Rights of Women in Africa Articles 1(k) and 4(2)(g), http://www.achpr.org/instruments/women-protocol/.

[34] Wessells, M. note 30, p. 90.

[35] Sarich, J., Olivier M.\& Bales K. (2016) Forced Marriage, Slavery, and Plural Legal Systems: An African Example. Human Rights Quarterly 38 2016, p. 450-476.

[36] Wison, A. Patriarchy: Feminist theory, in Kramarae C. \&. Spender D (eds.) (2000) International Encyclopedia of Women: Global Women's Issues and Knowledge, New York, p. 1495-1496.

[37] Chicago Project on security and Threats, http://cpostdata.uchicago.edu/search_new.php (Accessed $10 / 05 / 2018)$.

[38] Press release 'Nigeria Regional Conflict: Ten-fold increase in number of children used in 'suicide' attacks', UNICEF, http://www.unicef.org.uk/Media-centre/Pressreleases/Nigeria-Regional-Conflict-Ten-fold-increase-innumber-of-children-used-in-suicide-attacks/ (Accessed 21/07/ 2017).

[39] Abass, A. (2010) African peace and security architecture and the protection of human security, in Abass, A. (ed), Protecting Human Security in Africa, Oxford, p. 1-2, p. 77,89.

[40] Security Council resolution (S/RES/1325) on women and peace and security adopted on 31 October 2000.

[41] Other women writing on female suicide bombers include Skaine, R. (2006) Female suicide bombers, United States; Brunner, C. (2005) Female suicide bombers-Male suicide bombing? Looking for Gender in reporting the suicide bombings of the Israeli-Palestinian conflict. Global Society 19.1 2005, p. 29-48; July Rajan, V. G. (2011) Women suicide bombers: Narratives of violence, Oxford; Zenn, J. \&. Pearson, E. (2014) Women, Gender and the evolving tactics of Boko Haram. Journal of terrorism research 5.1.

[42] Von Knop, K. (2007) The female jihad: Al Qaeda's women. Studies in Conflict \& Terrorism, 30.5 2007, p. 397-414; Jacques K.\& Taylor, P. (2008) Male and female suicide bombers: different sexes, different reasons?. Studies in Conflict \& Terrorism 31.4 (2008), p. 304-326.

[43] Interview with Thomson Reuters Foundation, 'Fear spreads as child suicide bombings surge in West Africa", Reuters, 12 April 2016, http://www.dailymail.co.uk/wires/reuters/article3535466.
[44] Honwana, A. (2007) Child Soldiers in Africa, Pennsylvania, pp.73-78; Wessells, M. Child Soldiers, pp. 85-88; and Mazurana, D. \& McKay, S. (2001) Child soldiers What about the Girls?, Bulletin of Atomic Scientists, September/October:31-35. 2001, p.31-35.

[45] Zenn J., \& Pearson, E. (2014) Women, Gender and the Evolving Tactics of Boko Haram. Journal of Terrorism Research, 5.1.

[46] Children in Armed Conflict Report to the UN Security Council of 15 May 2014, A/68/878-S/2014/339, p.38, See also Number of Suicide Bombings Around World Surged $94 \%$ in 2014 Amid Rise of ISIS, http://www.haaretz.com/israelnews/.premium-1.635193 (Accessed 11/05/ 2018).

[47] Onuoha, F. (2014) Boko Haram and the evolving Salafi Jihadist threat in Nigeria, in Pérouse de Montclos, M. (ed) Boko Haram: Islamism, politics, security and the state in Nigeria, African Studies Centre, Leiden, p.163-173.

[48] Hoechner, H. (2014) Traditional Quranic students (almajirai) in Nigeria: Fair game for unfair accusations? in Pérouse de Montclos M. (ed), Boko Haram: Islamism, politics, security and the state in Nigeria, African Studies Centre, Leiden, p. 6384.

[49] Chothia, F. Boko Haram crisis: Nigeria's female bombers strike, BBC Africa, 6 August 2015 (http://www.bbc.co.uk/news/world-africa-28657085 (Accessed 11/05/ 2018).

[50] Nigerian city of Maiduguri 'attacked by five child bombers, $\begin{array}{llll}\text { BBC } & \text { News, } & 2 & \text { October } \\ 2015\end{array}$ http://www.bbc.co.uk/news/world-africa-34423311 (Accessed $11 / 05 / 2018$ ).

[51] Maina Maina, Boko Haram: 26 killed, 85 injured as 14 suicide bombers attack Maiduguri, Daily Post, 29 December 2015, http://dailypost.ng/2015/12/29/boko-haram-26-killed-85injured-as-14-suicide-bombers-attack-maiduguri/ (Accessed 3/01/2016).

[52] A picture of a suspected suicide killers appears in Nigerian Army nabs female suicide bomber in Adamawa, Live Ofofo, http://liveofofo.com/general-news/nigerian-army-nabs-femalesuicide-bomber-adamawa-photo.html/ (Accessed 4/01/ 2017).

[53] Female suicide bomber strikes Cameroon night spot, 26 July $2015 \quad 09: 14, \quad$ GMT, Aljazeera, http://www.aljazeera.com/news/2015/07/suicide-bomberstrikes-cameroon-night-spot-150726024720051.html (Accessed 11/11/2017).

[54] Kharitonova, N. (2015) Children used as suicide bombers in Central Asia, https://reliefweb.int/report/afghanistan/childrenused-suicide-bombers-central-asia, (Accessed 11/05/2018).

[55] 16 Suicide bombers attack Borno and Adamawa as Boko Haram challenges FG December deadline, NaijaGist.com, 29 December $2015 \mathrm{http} / /$ naijagists.com/16-female-suicidebombers-attack-borno-adamawa-in-24-hours-as-bokoharam-challenges-fg-december-deadline/

(Accessed 15/03/2018)

[56] McCane, L. 10-Year-Old Girl Suicide Bomber Kills 9 In Attack, Is Boko Haram To Blame?, 17 July 2015, http://www.inquisitr.com/2260018/10-year-old-girl-suicidebomber-kills-9-in-attack-is-boko-haram-to-blame/, (Accessed 11/05/2018). 
[57] According to a BBC interview with Martin Ewi, a researcher with South Africa's Institute for Security Studies (ISS), as quoted by Farouk Chothia, 'Boko Haram crisis: Nigeria's female bombers strike', BBC Africa, 6 August 2015, (http://www.bbc.co.uk/news/world-africa-28657085 (Accessed 17/11/ 2015).

[58] Opejobi, 30 December 2015 , http://dailypost.ng/2015/12/30/most-female-suicide-bombersdont-know-they-are-carrying-explosives-lai-mohammed/ (Accessed 3/01/2017).

[59] Boko Haram: How to save female suicide bombers, Vanguard, $29 \quad$ December 2015, http://www.vanguardngr.com/2015/12/boko-haram-how-tosave-female-suicide-bombers/ (Accessed 15 /03/ 2016).

[60] Drumbl, M. (2012) Reimagining Child Soldiers in International Law and Policy, Oxford, p. 102-116.

[61] AHG/Del.2 9XXX. See The African Union Counter Terrorism Framework, 23 Nov 2015 http://www.peaceau.org/en/page/64counter-terrorism-ct

[62] OAU Convention on the Prevention and Combating of Terrorism 1999 https://treaties.un.org/doc/db/Terrorism/OAUenglish.pdf.
[63] OAU Convention on the Prevention and Combating of Terrorism, article 2 .

[64] Protocol to the AU Convention on the Prevention and Combating of Terrorism,

[65] http://www.au.int/en/sites/default/files/treaties/7787-fileprotocol_oau_convention_on_the_prevention_combating_terr orism.pdf.

[66] Wessells, M. (2009) Child Soldiers, Cambridge, Massachusetts, p. 105.

[67] Optional Protocol to the CRC on Children in Armed Conflict was adopted by the United Nations General Assembly on 25 May 2000.

[68] Evans, M. D. (ed), (2006) International Law, Oxford, pp.121128 and 132-133.

[69] Optional Protocol Art 4(1).

[70] Paris Principles and Guidelines on Children Associated with Armed Forces or Armed Groups, 2007. 